\title{
Paths to power and ministers' durability: The Portuguese case
}

\author{
Carlos Seixas ${ }^{\mathrm{a}}$ and Manuel Luís Costa ${ }^{\mathrm{b}}$ \\ ${ }^{a}$ Católica Porto Business School, Universidade Católica Portuguesa, Porto, Portugal; ${ }^{b}$ \\ Center for Economics and Finance, School of Economics and Management of the \\ University of Porto, Porto, Portugal
}

CONTACT: Carlos Seixas cseixas@ porto.ucp.pt

\begin{abstract}
This research work is an inquiry into whether paths to power matter for the survival of ministers. Four different paths to ministerial positions are defined: 'Parliamentary', 'Party', 'Public Service', and 'Independent'. The theoretical perspective is based on both the ex-ante informational asymmetry and the moral hazard problem. A rigorous survival analysis was developed for the Portuguese case, and the main conclusion is that ministers who have attained power through the 'Party' path last longer in government than 'Parliamentary' ones.
\end{abstract}

Keywords: Paths to power; ministers' durability; survival; Portugal

This study addresses the question of the durability of individual ministers in a given government and carries out an empirical investigation into the Portuguese case.

Ministers are individually accountable as they play a vital role in policy formulation and implementation. Their duration in office matters in several respects, one of which is the ability to implement policies: if turnover is very high, the ability to implement good policies will be low as the minister concerned will not have the time needed to do so; if turnover is very low, the motivation to do what is best for society will also be low. Turnover of individual ministers in government may be determined by several factors (Fischer et al. 2012: 506). We raise the possibility that an explanation for turnover may 
lie in the paths to a ministerial position.

The studies on paths to power in Portugal (Costa Pinto and Tavares de Almeida 2008; Tavares de Almeida and Costa Pinto 2002) emphasize a special feature of the Portuguese democracy as of 1974, the significant number of ministers without political experience (which the authors refer to as independents). According to the authors, this derives from three factors: (i) the attempt to endow the executive with greater technical legitimacy and thus counterbalance the bias against the political class; (ii) the limited penetration of civil society by political parties, and (iii) the Prime Ministers' (PM) discretion.

An important finding of these studies is that:

'A significant proportion of those who ascend to executive offices are drawn from the universities or managerial positions, as specialists with high academic credentials and/or technical competences. This strong presence of nonpolitical ministers is also related with the attempts made by parties to promote their "openness towards civil society" in a political culture with strong feelings against the "political class", as well as with the increasing complexity and technocratic nature of policy-making. Although with less autonomous political power than party leaders, "independents" became so important to "quality" of cabinets that prime ministers think twice before sending them back to "civil society." (Costa Pinto and Tavares de Almeida 2008: 156-7).

However, the authors' approach is descriptive, and their assumptions have not been statistically validated. We, in turn, have conducted a study of ministerial tenure using rigorous empirical models to inquire whether paths to power matter for the survival of ministers. For this purpose, we have built an adequate database and carried out a survival analysis in order to study whether paths to power actually explain the survival of ministers and, if so, how they compare with each other. 
The relation of paths to power with the durability of ministers in governments can be explained on grounds of the ex-ante informational asymmetry and the moral hazard problem.

The main conclusion of the empirical analysis is that ministers who have attained power through the 'Party' path last longer than 'Parliamentary' ones. This conclusion also holds when interaction variables are defined between paths to power and interesting characteristics of ministers or governments.

This paper is organized as follows: the first section presents a literature review on ministerial durability and develops a theoretical prediction of the effects of paths to power on the durability of cabinet ministers in government; the second section addresses the main features of the Portuguese political system; the third section describes the data set and the survival model; the forth section provides a descriptive analysis of the data, whereas the fifth section analyzes the determinants of ministerial hazard rates; finally, conclusions are presented.

\section{Minister's durability and a principal-agent theoretical framework}

The theoretical framework that underlies the survival analysis of ministers in governments is the principal-agent framework as applied to parliamentary democracies; it relates to the broader theme of delegation of power and accountability in democracies (for a more comprehensive analysis see Besley 2006; Blondel 1985; Müller 2000; Strøm 1985; Strøm et al. 2003). In this literature, turnover is viewed as the result of informational problems (Huber and Martinez-Gallardo 2008).

However, given that we are studying the durability of ministers in governments, we focus on the delegation chain hinging on the position of the formateur of the government, i.e., the PM. Formally, the PM nominates and dismisses ministers, which, 
for the purpose of our study, is the central point of interest. In the theoretical explanation regarding the hiring and firing of a minister, we choose to consider the PM as the principal and the minister as the agent. This simplified way of referring to the agency problem involved does not imply that the delegation and accountability issues are confined to these two elements, it merely reflects the focus of the analysis that is undertaken here.

The survival analysis of ministers in governments is centred on the impact of paths to power. The definition of paths to power follows Blondel (1985: ch. 3); his classification, however, has been simplified and adapted to fit the interesting cases included in our sample: parliamentary, party, public service, and independence (for a more detailed definition, see below).

Apart from paths to power, a set of variables was chosen to represent other important underlying forces that explain the durability of ministers in governments, relating to the political experience of the minister, the political characteristics of the government and the president, and to other institutional features. Other important aspects regarding delegation and accountability must also be taken into consideration, namely: whether the government concerned is a coalition government and the minister belongs to a different party from that of the PM; the PM's term; the president's term; whether the president belongs to the same party as the PM; and the degree to which constitutional presidential powers affect the decisions to hire and fire a minister. In fact, PM decisions concerning appointment and dismissal are potentially influenced or constrained by other political bodies, namely the parliament, the parties, and the president.

Therefore, several aspects have been contemplated for the purpose of the statistical survival analysis, some of which were regarded as important and were 
addressed whenever adequate variables to capture them were available. We have looked for guidance in the literature (for a survey see Fischer et al. 2012), regarding the following aspects:

1. Experience: Parliamentary, party, and government. Parliamentary and/or party experience have a positive impact on ministerial tenure in Sweden (Bäck et al. 2008) and in Germany (Kaiser and Fischer 2009); actually, in Germany, ministers with parliamentary experience or experience as regional ministers last considerably longer (6.1 years) than others. In Belgium, $38 \%$ of the ministers have left office to move to a sub-national government (Dumont et al. 2008). In Canada, however, experience in a provincial cabinet has no impact on federal ministerial duration (Kerby 2010) and such experience actually shortens the durability of ministers in the UK (Berlinski et al. 2007) and in Spain (Jerez and Real-Dato 2005).

2. Other personal characteristics: Age, education: Duration is higher for younger ministers, and higher education leads to lower turnover (Bäck et al. 2008; Berlinski et al. 2007). Interestingly though, Dalvean (2012) finds that in the case of Australia, cognitive indicators are better predictors of ministerial appointment than representative factors.

3. Prime minister's or government's term of office: Ministerial survivor functions by prime ministerial term do not differ greatly in the UK (Berlinski et al. 2008), contrary to what happens in Spain (Real-Dato and Jerez-Mir 2008). Huber and Martinez-Gallardo (2008: 178) 'study how cabinet duration (defined by terminal events) and cabinet turnover (defined by the replacement of individuals within cabinets) are distinctive elements of government stability in parliamentary systems'. Nevertheless, Quiroz Flores (2009) shows that there is a correlation between the length of tenure of the PM and her foreign affairs ministers. 
4. The relevance of the portfolio: Indridason and Kam (2008) show that reshuffles are more frequent in the case of more influential portfolios. Yet the opposite effect has been found considering 19 parliamentary democracies (Huber and MartinezGallardo 2008) and in the UK (Berlinski et al. 2007). Another portfolio-related distinction is between non-contentious portfolios and portfolios presiding over divisive policy areas. In Russia, 'bureaucrat ministers', who manage non-contentious portfolios, last longer than 'political ministers', who preside over divisive policy areas (Shevchenko 2005). Similarly, in Germany, certain ministries such as defense or home affairs are more prone to resignation calls than, for instance, justice or postal affairs ministries (Fischer and Kaiser 2011).

5. Coalition governments: Portfolio allocation in multiparty governments has produced extensive research regarding executive governance and agency problems. One line of research attempts to make sense of existing institutional devices as coordination mechanisms between parties (Laver and Shepsle 1994, 1996; Saalfeld 2000). Another incorporates the issue of 'strategic allocation of portfolios to curb delegation perils' whereby the assignment of neighboring portfolios allows for an effective arrangement of 'cabinet decision-making processes, because parties obtain information, discuss, and agree at an earlier stage of the legislative process' (Fernandes et al. 2016: 1270, 1278).

6. Parliamentary versus presidential regime: The strength of the constraints faced by PMs in their decisions depends on the constitutional setup of powers parliamentary or presidential systems, or variations in-between. Of particular interest to our study is semi-presidentialism with its specificities. Under semi-presidentialism, heads of state affect the patterns of cabinet selection (Amorim Neto and Strøm 2006; Schleiter and Morgan-Jones 2010; Tavits 2009) and of government survival (Fernandes and Magalhães 2016). 
7. Cohabitation: In France the influence of both the PM and the parties increases during cohabitation, while the president wields greater influence under unified governments. Additionally, ministerial durability increases during cohabitation (Bucur 2017).

8. Resignation calls and popularity: In Canada calls for individual resignation increase turnover (Kerby 2009), a similar result to the one obtained for the UK regarding the first and second resignation calls (Berlinski et al. 2010). On the other hand, in Australia, the rate at which ministers leave office relatively to calls to leave it has decreased, but this may be related to the greater number of calls being made (Dowding et al. 2012). In Iceland, low public satisfaction with a minister increases turnover (Kristinsson 2008). Based on five parliamentary systems, Kam and Indridason (2005) conclude that reshuffles are more connected with the PM's low popularity rather than with that of the government. Moreover, in Australia, a higher complexity of government renders the responsibility of individual ministers relatively unimportant (Mulgan 2012).

9. Scandals: A scandal may lead to the resignation of a minister when costbenefit analysis compensates (Fischer et al. 2006). Dewan and Dowding (2005) show that resignations following a scandal restore popularity levels, even considering that scandals are bad for government. Thus, the PM has an incentive to fire the minister but only if she can replace him with a better one.

10. Outside jobs: Ministers may leave their office for attractive outsider jobs. The only study we are aware of relates to Germany, where the number of ministers who do so is low (8\%) (Kaiser and Fischer 2009).

The primary motivation of our study is to analyze the impact of paths to power on ministerial tenure, a subject that to the best of our knowledge has not yet been 
properly examined. In order to guide the survival analysis, we propose a theoretical framework based on the principal-agent model.

\section{Theoretical framework: a principal-agent model}

For the purpose of analyzing the durability of ministers in office and, consequently, the decision by the PM to dismiss a minister, underperformance is the only factor that matters. The bad performance of a minister can be interpreted by the PM in the light of two elements: on the one hand, the contribution of the ex-ante informational asymmetry (bad selection) and the moral hazard problem (sub-par quality of actions) to the event of bad performance and, on the other, the restrictions she faces when deciding to select and fire him. We analyse the impact of these two elements on durability according to the ministers' paths to power: parliamentary, party, public service, and independence.

\section{Selecting}

Firstly, there is an ex-ante informational asymmetry regarding the competence of the candidate for the ministerial post and the degree of scrutiny he is subject to by the PM to mitigate her lack of knowledge regarding not only the candidate's political and personal characteristics but also his abilities and knowledge with regard to the requirements for the specific office.

After the PM has concluded her screening effort and is ready to ponder the choice of minister, the degree of uncertainty is particularly diminished although not totally resolved. It is our contention that as regards competence, the degree of scrutiny of an 'Independent' is higher than that of a 'Party' or 'Parliamentary' minister, and as a consequence ex-ante information asymmetry is lower for the 'Independence' path. 'Public Service' is an intermediate path. Six main arguments seem reasonable: 
1. The 'Party'/'Parliamentary' advantage regarding information is not so significant as might be thought, given that ex-ante competence is not easily appraised;

2. The PM has strong incentives to carry out a thorough scrutiny of an 'Independent', given the party pressures and the setbacks she may endure in the case of a failure by this type of minister;

3. The scrutiny of an 'Independent' may be facilitated if he is an expert or a professional with proven ability in the field, which often happens in the choice of 'Independents';

4. 'Party'/‘Parliamentary' ministers are more likely to be office-seekers than 'Independent' ministers, forcing their way into the cabinet (Strøm 1990);

5. The nomination of a 'Party'/'Parliamentary' candidate for a given post may be made to please parties or interest groups;

6. Regarding the 'Public Service' path, the minister's previous activity is usually connected with the office he is chosen for, thus, his performance has already been assessed. However, this type of minister may be expected to be less scrutinized than an 'Independent', because the nomination to a 'Public Service' position may have been made to please parties or interest groups.

To conclude, let us consider the four paths to power. In order to mitigate the $e x$ ante informational asymmetry and given the restrictions previously explained, the PM should have collected more information and gained further knowledge about the competence of the 'Independent' minister, followed by 'Public Service', and then by the 'Parliamentary' or 'Party' minister.

As a result, we should expect a higher degree of competence from the minister about whom the PM knows more (Huber and Martinez-Gallardo 2008) which allows for the prediction of a higher turnover from the 'Party' or 'Parliamentary' paths, followed by the 'Public Service' path, and then by the 'Independence' path. 


\section{Firing}

Due to the moral hazard problem, the PM cannot fully identify the reason for a minister's bad performance and, yet, she must decide whether to fire him or not. Moreover, when considering taking this decision, she faces restrictions posed especially by her party or by members of her party in parliament. Given this context, paths to power will matter for the analysis of the durability of ministers.

On the one hand, it seems reasonable to posit that 'Parliamentary' or 'Party' paths to power should have effects of approximate magnitude on turnover. On the other hand, the PM faces higher constraints to fire a minister who attains power through the 'Parliamentary' or 'Party' paths than through the 'Public Service' or 'Independence' paths, since the PM may be subject to strong pressures or come to the conclusion that it is more convenient for her to retain a minister with a higher degree of proximity to the party.

Additionally, the PM faces some constraints to fire a minister coming from the 'Public Service' path, as he might be related to her party, than to fire a minister who reaches power through 'Independence'. We would argue that the PM faces less constraints to fire an 'Independent' than a non-independent minister.

In conclusion, a lower turnover from the 'Party' or 'Parliamentary' paths should be expected, followed by the 'Public Service' and the 'Independence' paths. The theoretical predictions are summed up in Table 1, taking the 'Independence' path as the reference base.

Table 1: Sign of the effects of the ex-ante information and moral hazard problems on turnover by Paths to Power 


\begin{tabular}{|l|c|c|}
\hline Path to Power & Ex-ante informational asymmetry & Moral hazard \\
\hline Party & ++ & -- \\
\hline Parliamentary & ++ & -- \\
\hline Public Service & + & - \\
\hline Independence & base & base \\
\hline
\end{tabular}

Note: The '+' sign means that there is an expected increase in turnover in comparison with the reference base; the '-' sign means that there is an expected decrease in turnover in comparison with the reference base.

\section{Features of the Portuguese political system}

According to the Portuguese Constitution, the President is elected by direct popular vote and can be re-elected for one term. The President appoints the PM considering the election results for the Assembly and after hearing the parties. The number of terms a PM can be appointed is not restricted. The legislature is elected for four years.

The President appoints the ministers on the PM's proposal (article 187) and the same applies to dismissals. Ministers can be appointed without any particular restrictions. The cabinet comes into being constitutionally (article 195) after the government's program has been approved in parliament. It is accountable to both the Assembly and the President, but it is only politically responsible to the former (article 191). However, the President may still dismiss the government in exceptional circumstances 'to ensure the regular function of the democratic institutions, upon hearing the Council of State' (article 195). ${ }^{1}$

To understand the balance of powers between the Assembly, the President, the PM, and the parties, a few notes are pertinent: Portugal is a semi-presidential regime, despite the growing power of the Prime Minister due to the reorganization of the executive branch and the 'governmentalization' of parties (Lobo 2005a, 2005b). Important features of the Portuguese President's powers are the legislative veto power and the power to refer legislation to the Constitutional Court; these are especially important in case of minority governments including parties that the President may 
oppose; however, the veto power is not so relevant under majority governments, even when the President and the PM belong to different parties. Moreover, it has been contended that the President's role in cabinet appointment and dismissal is of importance, especially at times of governmental instability (Amorim Neto and Lobo 2009).

The 'governmentalization' of parties has become an important trait of the Portuguese political system. 'By 'governmentalization of parties' we refer to the process by which party leadership bodies become increasingly composed of government members when the party holds executive offices. This control of the parties' executive bodies by the PM and her cabinet serves to minimise the party's independent input in government affairs' (Amorim Neto and Lobo 2009: 245). Thus, the 'governmentalization' of parties will imply that regarding the position of 'Party'/'Parliamentary' individual ministers, their incentive to act as agents of the party is diminished in favour of the PM (Lobo 2005b) and, therefore, ministers will be less likely to act as double agents (Müller 2000).

Parliamentary groups do not have a powerful position within the internal structure of parties (Tavares de Almeida and Costa Pinto 2002: 32). This is mainly the result of 'governmentalization' and the nature of party organization (Jalali 2007: ch. 4). The executive and legislative branches of government are fully separated: elected members of parliament who are appointed to the government need to give up their seats in parliament while in office.

The electoral law prevents competition by independent lists for Parliament and hence provides political parties with a dominant position as intermediaries in the political process which has no parallel in Western Europe (Sousa 1984). The electoral law is of the proportional type (Hondt's method). The effective number of 
parliamentary parties has decreased over the long run in the sample period from 3 to 4 before 1987 to around 2.5 afterwards (Freire and Lobo 2006).

During the late 1980s an evolution occurred towards a higher durability of governments and an increased prevalence of majority governments, together with an increased autonomy of PMs in their coordination role in the formation of government (Amorim Neto and Lobo 2009; Lobo 2005b). Coalition governments made up 53\% of the governments in the sample period, although the time-weighted percentage was $36 \%$. Two parties have dominated the formation of governments in the period covered: Partido Socialista (PS), a member of the Group of the Progressive Alliance of Socialists \& Democrats in the European Parliament; and Partido Social Democrata (PSD), a member of the European People's Party. Another party with ministers in coalition governments is Centro Democrático Social (CDS), also a member of the European People's Party.

There are two important studies of paths to power in Portugal: Tavares de Almeida and Costa Pinto (2002) and Costa Pinto and Tavares de Almeida (2008). The latter develops the first, focusing on the Second Republic (as from 1974). On the matter of government termination and ministerial de-selection, the authors assert that there is a significant number of independent ministers (ministers without political experience) who are maintained whenever a reshuffle or de-selection takes place which, in their opinion, indicates that party pressures do not constrain the PM (Costa Pinto and Tavares de Almeida 2008: 155).

Here we analyze the durability of government officers in Portugal focusing on the role of career paths and using a rigorous empirical model. Some features of the Portuguese political system may affect the survival of ministers in government. Firstly, it is a semi-presidential regime. Secondly, two related features of the Portuguese 
political system, the 'governmentalization' of parties and the weakness of parliamentary groups, are expected to have a strong impact on the durability of 'Party' $v s$ 'Parliamentary' ministers. Indeed, these features and the presence of a significant number of non-parliamentary but party members in the cabinet, as well as of independents, turn Portugal into a particularly interesting case study.

It should be noted, however, that the capacity to incorporate certain developments found in the literature in a way that is a statistically interesting and rich, is somewhat limited in a study on the case of Portugal. This applies above all to agency problems when the allocation of portfolios to ministers in multiparty governments is at stake, and the powers of the President to influence decisions on appointment and dismissal. Only very indirect variables that capture their potential effect can be obtained. Another interesting behavioral variable is scandals, however difficult it may be to measure them objectively.

\section{Data, empirical strategy, and survival model}

A new data set was collected. The data includes every Portuguese government from 1976 to November 2015. The data on the duration of ministers was obtained through the government website. ${ }^{2}$ Regarding the other features, information was gleaned from several sources: biographical dictionaries, official directories, newspapers, published CVs, etc. The data includes 222 individual ministers, and because some of them have served in more than one government there are 381 spells in office.

It is worth noting that from August 1978 to January 1980, there were three governments formed by presidential initiative where the delegation relationship between the PM and her ministers is overshadowed. For the survival model, our option is of not including these governments. The three governments concerned are highly atypical in 
comparison with the rest of the governments: (i) they lasted much less: 163.7 days versus 803.1 days; (ii) given short government durations, there were no minister failures; (iii) parties had no influence on the formation of these governments; (iv) the distribution of paths to power is markedly different than that of the rest of the sample: 'Independence' and 'Public Service' prevail, representing $87 \%$ of the ministers in governments of presidential initiative compared with $25 \%$ in prime ministerial governments. Consequently, the interpretation of the results would be jeopardized according to our agency approach based on the delegation involving the prime minister, parliament, and parties.

With regard to the path through which a minister attains power, a precise definition is necessary for empirical purposes (see also Table A1 in the Appendix):

- A 'Party' minister is a party member or has run for the party in an election.

- A 'Parliamentary' minister had been previously elected as a member of parliament; it should be noticed that if someone was elected and subsequently appointed as a minister in that legislature, we opt to classify him in this type even though he may not have been actually a member of parliament.

- A 'Public Service' minister has previously worked for a government agency.

- An 'Independent' minister does not qualify for any of the 'Parliamentary', 'Party', or 'Public Service' paths. Our notion of 'Independence' is residual and is not related to any particular experience. Minister Mariano Gago is an interesting example. He was an academic, a full professor and had had no pre-ministerial involvement in the political game. Due to his know-how, he served in 4 governments of Partido Socialista as Minister of Science, Technology, and Higher Education. Prior to this, however, he had been appointed director of the 
National Board for Scientific and Technical Research in a Partido Social Democrata government.

As to the durability analysis, this consists in identifying the factors that affect the duration of a political agent and in explaining how these factors operate in the survival of the political agent in government or, conversely, in his dismissal from government. Durability is a property inherent to the minister and depends on his personal characteristics as well as on the context he is in, namely the political regime and the institutional environment. Different counting rules can be used, with no definition being universally accepted in the literature. Fischer et al. (2012: 508) discuss the options and their opinion is that duration studies should consider 'uninterrupted ministerial tenure across various governments as one spell, whereas most studies on durability are more rigorous and operate with a definition of a "ministerial spell as the length of time which a minister serves in a given administration (Berlinski et al. 2007)."' In fact, Berlinski et al. (2007, 2012), who study the factors that influence the durability of ministers in government, opt for the latter definition. With a similar purpose, Jäckle (2013) follows the former definition.

Regarding the empirical strategy, a period in office will be measured as the length of time from the moment a minister joins the government until he leaves office, or the government terminates. As to the government, it ends when a new government is formed. The termination of a minister due to government termination (end of legislature or government failure), death, or illness, is not considered a failure in our empirical analysis.

In order to assess ministers' durability, the hazard rate for each minister in government at any given point in time $t$ is estimated, that is, the probability that if a 
minister has survived to $t$, he will leave the government in the next instant (in other words, he will fail). The hazard rate is the ratio between the failure rate and the survival function.

As the distribution in time of the risk of exiting the government is not clear, the statistical analysis uses the semi-parametric Cox Proportional Hazard models (Cox 1972), which enables to construct the covariates to ministerial duration without the need to make specific assumptions about the shape of the hazard function. ${ }^{3}$ As the information is organized in multiple record data, the observations for the same subject are not conditionally independent (Box-Steffensmeier and Jones 2004). This effect produces incorrect standard errors. In order to address this problem, and given the fully parametric setting established here, we have used Lin-Wei standard errors clustered on each minister (Lin and Wei 1989). This procedure relaxes the assumption that observations for the same minister are independent and produces a robust variancecovariance matrix and correct standard errors without changing the coefficient estimates.

We define $t_{j g}$ as the duration of minister $j$ in government $g$ where a minister starts a new ministerial spell every time he enters government independently of having had spells in previous governments. However, the duration of a minister in a government depends not only on paths to power but also on the personal characteristics of ministers, which is dealt with by adding other variables to the specification - see Table A2 in the Appendix. ${ }^{4}$ Furthermore, a set of institutional features that characterize the government to which the minister belongs are equally relevant to the model specification - see Table A3 in the Appendix.

Thus, we will adopt the following empirical specification in the proportional hazard format, taking variable $i$ as the base:

$$
\mathrm{h}_{\mathrm{jgt}}=\lambda_{\mathrm{PM}}\left(\mathrm{t}_{\mathrm{jg}}\right)-\exp \left[\alpha_{1} \cdot \mathrm{p}+\alpha_{2} \cdot \mathrm{pp}+\alpha_{3} \cdot \mathrm{sp}+\beta_{0} \cdot \mathrm{Xjg}+\gamma_{0} \cdot \mathrm{Yg}\right],(1)
$$


where $\lambda_{P M}\left(t_{j g}\right)$ is the minister's baseline hazard at $t_{\mathrm{jg}}$ in a given Prime Ministerial term, $\mathrm{X}_{\mathrm{jg}}$ a vector of the individual characteristics (see Table A2), and $\mathrm{Y}_{\mathrm{g}}$ a vector of the government characteristics (see Table A3).

\section{Descriptive analysis}

There are 336 observations in the dataset. As shown in Table 2, each minister lasted 644 days on average (less than 2 years), but the standard deviation is high; actually, the maximum amount of time a minister served was 1,689 days and the minimum was 14 days.

Table 2: Summary statistics

\begin{tabular}{|l|c|c|}
\hline Variable & Mean & Std. Dev. \\
\hline Days in office & 644,01 & 448,36 \\
\hline Party & 0,44 & 0,50 \\
\hline Parliamentary & 0,31 & 0,46 \\
\hline Public Service & 0,06 & 0,23 \\
\hline Independent & 0,19 & 0,4 \\
\hline
\end{tabular}

$(\mathrm{N}=336)$

Considering the personal characteristics, Table 3 shows that ministers with any sort of previous experience in government attain power mainly through the 'Party' path. In fact, while for the complete set of ministers, $44 \%$ attained power through the 'Party' path, for different subsets of ministers with previous experience in government, the share of the 'Party' path varies from $56 \%$ to $67 \%$. Moreover, the same trends are observed for the 'Party' and 'Parliamentary' paths together.

Table 3: Personal characteristics of the ministers and paths to power

\begin{tabular}{|l|l|l|l|l|l|}
\hline \multirow{2}{*}{ Number } & \multicolumn{4}{|c|}{ Distribution } \\
\cline { 3 - 6 } & Party & Parliamentary & $\begin{array}{c}\text { Public } \\
\text { Service }\end{array}$ & Independent \\
\hline
\end{tabular}




\begin{tabular}{|l|c|c|c|c|c|}
\hline $\begin{array}{l}\text { Experience } \\
\text { as minister }\end{array}$ & 73 & 0,58 & 0,29 & 0,01 & 0,12 \\
\hline $\begin{array}{l}\text { Experience } \\
\text { as junior } \\
\text { minister }\end{array}$ & 89 & 0,67 & 0,20 & 0,02 & 0,11 \\
\hline $\begin{array}{l}\text { Served as } \\
\text { minister in } \\
\text { the previous } \\
\text { government }\end{array}$ & 80 & 0,59 & 0,26 & 0,05 & 0,10 \\
\hline $\begin{array}{l}\text { Served as } \\
\text { junior } \\
\text { minister } \\
\text { (previous or } \\
\text { current } \\
\text { govt.) }\end{array}$ & 67 & 0,56 & 0,28 & 0,04 & 0,12 \\
\hline $\begin{array}{l}\text { Top } \\
\text { portfolio }\end{array}$ & 52 & 0,54 & 0,15 & 0,04 & 0,27 \\
\hline All & 336 & 0,44 & 0,31 & 0,06 & 0,19 \\
\hline
\end{tabular}

This is a consequence of several features of the political system: the insufficient power that parliamentary groups achieve within the parties' internal structure; the residual value of the 'Public Service' path; and the low presence of 'Independent' ministers with previous experience in government. Actually, in relative terms, we can see that only a small fraction of experienced ministers is 'Independent'; theoretically this might either be explained either by the small percentage of 'Independents' selected for government or by the small percentage of those ministers who are re-selected. Given that there is a significant presence of 'Independent' ministers, this may indicate that 'Independents' tend not to be re-appointed in future governments, possibly because they were not be able to build up their political careers. Indeed, only $12 \%$ of the ministers who were promoted from 'junior ministers' within the current government or after having served in the previous government are 'Independents', whereas for ministers who had attained power through the 'Party', 56\% had previously served as 'junior ministers' in the current or in the previous government. 
It is also possible to conclude that more than half of the ministers with a top portfolio are 'Party' ministers (54\%). However, 'Independents' are well represented in such portfolios with $27 \%$, which is related to their expertise in specific subjects, particularly in finance.

In Table 4, it can be observed that in PSD governments $80 \%$ of the selected ministers have attained power through the 'Party', whereas only $3 \%$ have ascended through 'Parliament'. The inverse happens in PS governments, where 'Independents' and 'Parliamentary' are preponderant, with 'Independents' attaining 28\% and 'Parliamentary' $36 \%$ of the ministers. In PSD-CDS governments, 'Parliament' ministers have also shown a high incidence with $41 \%$ of the ministers.

Table 4: Parties in governments and paths to power

\begin{tabular}{|l|c|c|c|c|c|}
\hline \multirow{2}{*}{} & \multirow{2}{*}{ Number } & \multicolumn{4}{|c|}{ Distribution } \\
\cline { 3 - 6 } & & Party & Parliamentary & $\begin{array}{c}\text { Public } \\
\text { Service }\end{array}$ & Independent \\
\hline PS & 126 & 0,3 & 0,36 & 0,05 & 0,29 \\
\hline PSD & 64 & 0,80 & 0,03 & 0,05 & 0,12 \\
\hline PSD/CDS & 125 & 0,37 & 0,41 & 0,08 & 0,14 \\
\hline PS/PSD & 21 & 0,57 & 0,29 & 0,00 & 0,14 \\
\hline All & 336 & 0,44 & 0,31 & 0,06 & 0,19 \\
\hline
\end{tabular}

According to Table 5, the representation of paths is similar in the first and in the second terms; a third term took place only once, not allowing any conclusions.

Table 5: Terms and paths to power

\begin{tabular}{|c|c|c|c|c|c|}
\hline & \multirow{2}{*}{ Number } & \multicolumn{4}{|c|}{ Distribution } \\
\cline { 3 - 6 } & & Party & Parliamentary & $\begin{array}{c}\text { Public } \\
\text { Service }\end{array}$ & Independent \\
\hline Term 1 & 191 & 0,41 & 0,34 & 0,05 & 0,20 \\
\hline Term 2 & 119 & 0,39 & 0,34 & 0,07 & 0,20 \\
\hline Term 3 & 26 & 0,85 & 0,00 & 0,04 & 0,11 \\
\hline
\end{tabular}




\begin{tabular}{|l|l|l|l|l|l|}
\hline All & 336 & 0,44 & 0,31 & 0,06 & 0,19 \\
\hline
\end{tabular}

Finally, Table 6 shows that under cohabitation or in the president's second term there is slightly more 'Party' ministers and slightly less 'Independent' ministers than for the average of each of these types of ministers.

Table 6: President and Paths to Power

\begin{tabular}{|l|c|c|c|c|c|}
\hline & \multirow{2}{*}{ Number } & Party & Parliamentary & $\begin{array}{c}\text { Public } \\
\text { Service }\end{array}$ & Independent \\
\cline { 3 - 6 } & & 0,5 & 0,26 & 0,06 & 0,17 \\
\hline Cohabitation & 250 & 0,47 & 0,32 & 0,06 & 0,15 \\
\hline $\begin{array}{l}\text { Presidents in } \\
\text { second term }\end{array}$ & 158 & 0,44 & 0,31 & 0,06 & 0,19 \\
\hline All & 336 & & \multicolumn{4}{|c|}{ Distribution } \\
\hline
\end{tabular}

As for survival profiles, Figure 1 presents the Kaplan-Meier survivor function applied to all ministerial spells in the sample. The data reveal that the chances of a minister remaining in office drop sharply after the two-year mark, the period when reshuffles have a higher incidence.

Figure 1: Ministerial survival function ABOUT HERE

\section{The determinants of ministerial hazard rates}

The results of the standard Cox models using as a base the 'Independence' path are displayed in Table 7. Model (1) uses the main variables regarding paths to power. Model (2) uses these variables together with the ministers' personal characteristics. Model (3) uses the institutional features of the government the ministers are a part of 
(terms and the PM fixed effects are not included), instead of their personal characteristics. Model (4) merges models (2) and (3). Model (5) further adds the terms variables. As for Model (6), it adds the PM fixed effects but removes the institutional features of the government, since the goal in this case is to specify a hazard rate for each PM. Finally, Model (7) uses the main variables, the personal characteristics, and an interaction between the PMs and their terms.

Table 7: Hazard rates for Cox models for all ministers - 'Independence' path as base

\begin{tabular}{|l|c|c|c|c|c|c|c|}
\hline Variables & $(1)$ & $(2)$ & $(3)$ & $(4)$ & $(5)$ & $(6)$ & $(7)$ \\
\hline Party & $\begin{array}{c}0.742 \\
(0.258)\end{array}$ & $\begin{array}{c}0.651 \\
(0.250)\end{array}$ & $\begin{array}{c}0.727 \\
(0.282)\end{array}$ & $\begin{array}{c}0.704 \\
(0.290)\end{array}$ & $\begin{array}{c}0.738 \\
(0.306)\end{array}$ & $\begin{array}{c}0.555 \\
(0.221)\end{array}$ & $\begin{array}{c}0.563 \\
(0.226)\end{array}$ \\
\hline Parliamentary & $\begin{array}{c}1.074 \\
(0.399)\end{array}$ & $\begin{array}{c}1.136 \\
(0.429)\end{array}$ & $\begin{array}{c}1.360 \\
(0.531)\end{array}$ & $\begin{array}{c}1.477 \\
(0.594)\end{array}$ & $\begin{array}{c}1.489 \\
(0.598)\end{array}$ & $\begin{array}{c}1.061 \\
(0.419)\end{array}$ & $\begin{array}{c}1.067 \\
(0.414)\end{array}$ \\
\hline Public Service & $\begin{array}{c}0.996 \\
(0.592)\end{array}$ & $\begin{array}{c}0.920 \\
(0.577)\end{array}$ & $\begin{array}{c}0.937 \\
(0.586)\end{array}$ & $\begin{array}{c}0.962 \\
(0.619)\end{array}$ & $\begin{array}{c}1.003 \\
(0.633)\end{array}$ & $\begin{array}{c}1.009 \\
(0.610)\end{array}$ & $\begin{array}{c}1.054 \\
(0.652)\end{array}$ \\
\hline $\begin{array}{l}\text { Personal } \\
\text { Characteristics }\end{array}$ & No & Yes & No & Yes & Yes & Yes & Yes \\
\hline $\begin{array}{l}\text { Political } \\
\text { Characteristics }\end{array}$ & No & No & Yes & Yes & Yes & No & No \\
\hline Terms & No & No & No & No & Yes & Yes & No \\
\hline Prime Ministers & No & No & No & No & Yes & No \\
\hline $\begin{array}{l}\text { Terms x Prime } \\
\text { Ministers }\end{array}$ & No & No & No & No & No & No & Yes \\
\hline Observations & 336 & 336 & 336 & 336 & 336 & 336 & 336 \\
\hline $\begin{array}{l}\text { Schoenfeld } \\
\text { (d.f.) }\end{array}$ & $\begin{array}{c}1.87 \\
(3)\end{array}$ & $\begin{array}{c}3.71 \\
(8)\end{array}$ & $\begin{array}{c}10,07 \\
(11)\end{array}$ & $\begin{array}{c}9,17 \\
(16)\end{array}$ & $\begin{array}{c}9,65 \\
(17)\end{array}$ & $\begin{array}{c}8.54 \\
(17)\end{array}$ & $\begin{array}{c}6.62 \\
(22)\end{array}$ \\
\hline p-value & 0.6 & 0.8819 & 0.5239 & 0.8818 & 0.9175 & 0.9531 & 0.9993 \\
\hline
\end{tabular}

Note: Standard errors in parentheses. ${ }^{*} * \mathrm{p}<0.01,{ }^{*} \mathrm{p}<0.05,{ }^{*} \mathrm{p}<0.1$. See Tables A1, A2 and A3 for the definition of the variables.

We can conclude from Table 7 that the 'Party', 'Parliamentary', and 'Public Service' paths show a turnover pattern no different from the 'Independence' path. ${ }^{5}$ This may mean that the moral hazard and ex-ante informational effects cancel each other out for each minister. The possibility exists that the flexibility of a PM in firing ministers 
who have attained power through the 'Independence' or 'Public Service' paths is compensated by their higher competence. The opposite may occur for ministers who have attained power through the 'Parliament' and 'Party' paths, their possible lower competence being compensated by the PM's lower flexibility in firing them.

In our study, the paths to power are compared with each other. The conclusions from Table 7 refer to the case where 'Independence' is the base that all the other paths are compared with. In the Appendix, we can find the hazard ratios for Cox models using as base the 'Public Service' and 'Parliamentary' paths, as shown in Table A4 and Table A5, Erro! A origem da referência não foi encontrada. respectively. As for the 'Public Service' path as base, no difference in turnover is observed. With respect to the 'Parliamentary' base, however, a conclusion can be drawn.

In fact, a 'Party’ minister lasts longer than a 'Parliamentary’ one (Table A5). One possible explanation is that a 'Party' minister who is not or was not in parliament but is connected with the party may face higher competition in order to be selected as minister and be therefore comparatively more scrutinized and expected to be more competent. Another would be that parliamentary groups do not have a powerful position within the internal structure of parties; in this case, the less powerful position within the party structure of 'Parliamentary' in relation to 'Party' ministers might make the former more likely to be fired than the latter, given a similar degree of underperformance.

It could be argued that the analysis is biased because it includes ministers who took office in mid-term following a reshuffle or dismissal. However, our results persist even if only ministers who took office at the inauguration of the government are considered, ${ }^{6}$ which strongly reinforces our conclusions. Another conclusion can yet be drawn: in some models 'Independents' happen to last less than 'Party' ministers (see models (6) and (7) in Table A6 in the Appendix). 


\section{Interaction variables}

Interactions between paths to power and variables that define ministerial characteristics may help to capture differences in durability between paths to power in specific situations. Close attention should be given to the possibility of collinearity between those new interaction variables and the variables that are used to control the survival analysis. Therefore, interactions of the different paths to power with the following variables have been created: experience or no experience; ${ }^{7}$ government's term; ${ }^{8}$ leftor right-wing government; ${ }^{9}$ minority or majority government $;{ }^{9}$ coalition or non-coalition government. ${ }^{10}$

The results reinforce the general conclusion that 'Party' ministers last longer than 'Parliamentary' ministers. This happens when each characteristic of the 'Party' ministers is present: they are experienced; in the first term; in a left-wing government; in a majority government; and in a non-coalition government.

The same conclusions apply if only those ministers who were appointed at the inauguration of the government are considered. Actually, conclusions are even stronger for 'Party' ministers in left-wing governments and in non-coalition governments.

It is also possible to conclude that 'Independent' ministers in other terms than the first last less than 'Party' ministers in the first term (see Table A7 in the Appendix).

Furthermore, a sub-sample analysis was carried out, but the conclusions are very similar to those reached for interaction variables (see Appendix ${ }^{11}$ ).

\section{Conclusion}

In this article we have studied the durability of ministers in a government by the means of survival analysis in order to inquire into how ministerial durability is affected by 
different paths to power. This has not been addressed in the literature using rigorous empirical models, as opposed to what is found in the existing descriptive literature. Four ways to become a minister have been considered: through the 'Parliamentary', 'Party', 'Public Service', and 'Independence' paths. The first two are the main forms of access to ministerial duties in the Portuguese case, and 'Independence' represents $20 \%$, while 'Public Service' plays a rather minor role.

An informational framework underlies the explanation of ministers' durability. As 'Party' or 'Parliamentary' ministers are more difficult to fire given their stronger standing in the party, these types would be expected to last longer than 'Independent' ministers. However, 'Independent' ministers should be more competent as their ex-ante screening is more rigorous, so we would expect that they last longer than 'Party' or 'Parliamentary' ministers. 'Public Service' ministers were expected at an intermediate stage.

The two main findings of the survival model are the following. First, if we compare the 'Party' and 'Parliamentary' paths with the two other paths, no significant difference in durability is found. However, if we compare those two paths, it is possible to conclude that 'Party' ministers last longer than 'Parliamentary' ministers. Our theoretical proposition is that this may be due to a combination of two effects, the selecting and firing ones. The selecting effect is mainly explained by the fact that 'Party' ministers face higher competition, as there are more possible candidates to be chosen as ministers than 'Parliamentary' ones, which translates into an expected greater competence of 'Party' ministers; if this is the case, 'Party' ministers face fewer situations where they may be fired compared with 'Parliamentary' ones. The firing effect is mainly explained by the fact that in Portugal, parliamentary groups do not hold a powerful position within the internal structure of parties; in this case, such weaker 
position of 'Parliamentary' in relation to 'Party' ministers may make them more susceptible of being fired, given a similar degree of underperformance.

Second, our survival analysis indicates that the durability of 'Independent' ministers is not different from that of any other path. This may result from the fact that, even though they are more likely to be fired than ministers who have been appointed via other paths, 'Independents' are more competent, which may allow them not to face as many situations in the sequence of which they might be fired. That is to say, the moral hazard and the ex-ante informational asymmetry problems might cancel out each other. Interestingly, this result is compatible with the statement in Costa Pinto and Tavares de Almeida (2008: 155) that party pressures do not constrain the PM in her decision to dismiss 'Independents'.

For a more thorough analysis and to address possible statistical problems, we have carried out a detailed analysis in which interaction variables were defined between paths to power and interesting characteristics of ministers or governments. The main conclusion confirms the results obtained for the basic set of models.

The empirical analysis is a case study that focuses on the influence of paths to power on the survival of individual ministers in government, controlling for a set of relevant measurable personal or institutional variables. However, being a case study, what it gains in detail of explanatory variables and in the depth of the statistical analysis comes at a cost of loss of generality. Many empirical studies in the literature are of a comparative nature, often using statistically simpler models and less specific variables, which therefore only allow for a more superficial grasp of the effects under analysis. Be that as it may, our detailed analysis may well help to understand the findings of these comparative studies regarding Portugal. 
Another aspect to emphasize is that this study deals with a type of political system which has some parallels with other third wave democracies. Since Portugal is a semi-presidential system with a proportional electoral law and where parties are 'governamentalized', our analysis allows to observe how the balance of powers between the PM, the parties and the president plays on the durability of ministers. Therefore, our case study may matter in comparative terms with countries that show institutional similarities with Portugal, such as third wave democracies.

\section{Acknowledgements}

We wish to thank the two anonymous reviewers for their comments and suggestions.

\section{Notes on contributors}

Carlos Seixas is a Professor of Economics at Católica Porto Business School.

$\mathrm{PhD}$ in Economics from School of Economics and Management of the University of Porto, with a specialization in Political Economy. He was a Visiting Researcher at the Faculty of Economics and Management, University of Kassel, in 2014. Research interests: Public Economics and Political Economy [cseixas@ porto.ucp.pt].

Manuel Luís Costa is an Associate Professor at School of Economics and Management of the University of Porto. $\mathrm{PhD}$ in Economics from the University of South Carolina. Research interests: Public Choice and Industrial Organization [mlcosta@ fep.up.pt].

\section{ORCID}

Carlos Seixas (iD https://orcid.org/0000-0002-0167-4870

\section{Notes}


${ }^{1}$ Before the constitutional revision of 1982, the President was also granted powers to dissolve the government in normal circumstances.

${ }^{2}$ http://www.portugal.gov.pt/pt/o-governo/arquivo-historico/governos-constitucionais.aspx

${ }^{3}$ The use of Ordinary Least Squares causes problems as a result of data censoring given that

OLS violates the assumption of normally distributed error terms (Box-Steffensmeier and Jones 1997).

${ }^{4}$ Other characteristics were considered in the regressions, such as holding a $\mathrm{PhD}$, if he had studied in Porto or Lisbon, his profession and age, but none showed significant explanatory power.

${ }^{5} \mathrm{~A}$ table with the results with all the variables is presented in Table A8 in the Appendix.

${ }^{6}$ In this case, the variable Ss will only represent the 'Junior ministers' who have served in the previous government.

${ }^{7}$ Due to collinearity, experience as a control variable is dropped and models (2) and (4) are eliminated.

${ }^{8}$ Due to collinearity, term as a control variable is dropped and models (5) and (7) are eliminated.

${ }^{9}$ Due to collinearity, the variable indicating the party that supports the government is dropped.

${ }^{10}$ Due to collinearity, the variable that indicates if the minister belongs to a supporting minority party and the one that gives the parliamentary percentage of the minority party supporting the government are dropped.

${ }^{11} \mathrm{https}: / /$ figshare.com/s/c8ae7d16ebdd785e43d1

\section{References}

Amorim Neto, Octávio, and Marina Costa Lobo (2009). 'Portugal's semipresidentialism (re)considered: An assessment of the president's role in the policy process, 1976-2006', European Journal of Political Research, 48:2, 234 255.

Amorim Neto, Octávio, and Kaare Strøm (2006). 'Breaking the parliamentary chain of delegation: Presidents and non-partisan cabinet members in European democracies', British Journal of Political Science, 36:4, 619-643.

Bäck, Hanna, Thomas Persson, Kåre Vernby, and Helena Wockelberg (2008). 'In tranquil waters: Swedish cabinet ministers in the postwar era', in Keith Dowding 
and Patrick Dumont (eds.), The Selection of Ministers in Europe: Hiring and firing. London: Routledge, 159-178.

Berlinski, Samuel, Torun Dewan, and Keith Dowding (2007). 'The length of ministerial tenure in the UK, 1945-1997', British Journal of Political Science, 37:2, 245262.

Berlinski, Samuel, Torun Dewan, and Keith Dowding (2008). 'Choosing, moving and resigning at Westminster, UK', in Keith Dowding and Patrick Dumont (eds.), The Selection of Ministers in Europe: Hiring and firing. London: Routledge, $58-78$.

Berlinski, Samuel, Torun Dewan, and Keith Dowding (2010). 'The impact of individual and collective performance on ministerial tenure', The Journal of Politics, 72:2, $559-571$.

Berlinski, Samuel, Torun Dewan, and Keith Dowding (2012). Accounting for Ministers: Scandal and survival in British government 1945-2007. New York: Cambridge University Press.

Besley, Timothy (2006). Principled Agents? The Political Economy of Good Government. Oxford: Oxford University Press.

Blondel, Jean (1985). Government Ministers in the Contemporary World. London: SAGE.

Box-Steffensmeier, Janet M., and Bradford S. Jones (1997). 'Time is of the essence: Event history models in political science', American Journal of Political Science, 41:4, 1414-1461.

Box-Steffensmeier, Janet M., and Bradford S. Jones (2004). Event History Modeling: A Guide for Social Scientists. New York: Cambridge University Press.

Bucur, Cristina (2017). 'Cabinet ministers under competing pressures: Presidents, prime ministers, and political parties in semi-presidential systems', Comparative European Politics, 15:2, 180-203.

Costa Pinto, António, and Pedro Tavares de Almeida (2008). 'Portugal: The primacy of "independents", in Keith Dowding and Patrick Dumont (eds.), The Selection of Ministers in Europe: Hiring and firing. London: Routledge, 147-158.

Cox, David R. (1972). 'Regression models and life-tables', Journal of the Royal Statistical Society. Series B (Methodological), 34:2, 187-202. 
Dalvean, Michael (2012). 'Predicting cabinet ministers: A psychological approach', in Keith Dowding and Chris Lewis (eds.), Ministerial Careers and Accountability in the Australian Commonwealth Government. Canberra: ANU E Press, 35-65.

Dewan, Torun, and Keith Dowding (2005). 'The corrective effect of ministerial resignations on government popularity', American Journal of Political Science, 49:1, 46-56.

Dowding, Keith, Chris Lewis, and Adam Packer (2012). 'The pattern of forced exits from the ministry', in Keith Dowding and Chris Lewis (eds.), Ministerial Careers and Accountability in the Australian Commonwealth Government. Canberra: ANU E Press, 115-134.

Dumont, Patrick, Stefan Fiers, and Régis Dandoy (2008). 'Belgium: Ups and downs of ministerial careers in a partitocratic federal state', in Keith Dowding and Patrick Dumont (eds.), The Selection of Ministers in Europe: Hiring and firing. London: Routledge, 125-146.

Fernandes, Jorge M., and Pedro C. Magalhães (2016). 'Government survival in semipresidential regimes', European Journal of Political Research, 55:1, 61-80.

Fernandes, Jorge M, Florian Meinfelder, and Catherine Moury (2016). 'Wary partners: Strategic portfolio allocation and coalition governance in parliamentary democracies', Comparative Political Studies, 49:9, 1270-1300.

Fischer, Jörn, Keith Dowding, and Patrick Dumont (2012). 'The duration and durability of cabinet ministers', International Political Science Review, 33:5, 505-519.

Fischer, Jörn, and André Kaiser (2011). 'Wie gewonnen, so zerronnen? Selektions- und Deselektionsmechanismen in den Karrieren deutscher Bundesminister', Politische Vierteljahresschrift, Special Issue 44, 192-212.

Fischer, Jörn, André Kaiser, and Ingo Rohlfing (2006). 'The push and pull of ministerial resignations in Germany, 1969-2005', West European Politics, 29:4, 709-735.

Freire, André, and Marina Costa Lobo (2006). 'The Portuguese 2005 legislative election: Return to the left', West European Politics, 29:3, 581-588.

Huber, John D., and Cecilia Martinez-Gallardo (2008). 'Replacing cabinet ministers: Patterns of ministerial stability in parliamentary democracies', American Political Science Review, 102:2, 169-180. 
Indridason, Indridi, and Christopher Kam (2008). 'Cabinet reshuffles and ministerial drift', British Journal of Political Science, 38:4, 621-656.

Jäckle, Sebastian (2013). 'Ministerial turnover in the German Länder (1991-2010)', Zeitschrift für Vergleichende Politikwissenschaft, 7:1, 27-48.

Jalali, Carlos (2007). Partidos e Democracia em Portugal: 1974-2005: Da Revolução ao Bipartidarismo. Lisboa: Imprensa de Ciências Sociais.

Jerez-Mir, Miguel, and José Real-Dato (2005). 'Remodelaciones ministeriales en los gobiernos espanoles (1977-2004)'. VII Congreso de la Asociación Espanola de Ciencia Politica y de la Administración (AECPA), Madrid.

Kaiser, André, and Jörn Fischer (2009). 'Linkages between parliamentary and ministerial careers in Germany, 1949-2008: The Bundestag as recruitment pool', German Politics, 18:2, 140-154.

Kam, Christopher, and Indridi Indridason (2005). 'The timing of cabinet reshuffles in five Westminster parliamentary systems', Legislative Studies Quarterly, 30:3, $327-363$.

Kerby, Matthew (2009). 'Calls of the wild: Resignation requests in the Canadian House of Commons: 1957-2008'. Annual Conference of the Canadian Political Science Association, Ottawa, Ontario.

Kerby, Matthew (2010). 'The patterns and effects of subnational political experience on federal level career paths in Canada: 1867-2008'. Annual Conference of the Canadian Political Science Association, Montreal, Quebec.

Kristinsson, Gunnar H. (2008). 'More safe than sound? Cabinet minister in Iceland', in Keith Dowding and Patrick Dumont (eds.), The Selection of Ministers in Europe: Hiring and firing. London: Routledge, 194-203.

Laver, Michael, and Kenneth A. Shepsle (eds.) (1994). Cabinet Ministers and Parliamentary Government. Cambridge: Cambridge University Press.

Laver, Michael, and Kenneth A. Shepsle (1996). Making and Breaking Governments: Cabinets and legislatures in parliamentary democracies. Cambridge: Cambridge University Press.

Lin, Danyu L., and Lee-Jen Wei (1989). 'The robust inference for the Cox proportional hazards model', Journal of the American Statistical Association, 84:408, 10741078. 
Lobo, Marina Costa (2005a). 'The presidentialization of Portuguese democracy?', in Thomas Poguntke and Paul Webb (eds.), The Presidentialization of Politics. A comparative study of modern democracies. Oxford: Oxford University Press, 269-288.

Lobo, Marina Costa (2005b). Governar em Democracia. Lisboa: Imprensa de Ciências Sociais.

Mulgan, Richard (2012). 'Assessing ministerial responsibility in Australia', in Keith Dowding and Chris Lewis (eds.), Ministerial Careers and Accountability in the Australian Commonwealth Government. Canberra: ANU E Press, 177-193.

Müller, Wolfgang C. (2000). 'Political parties in parliamentary democracies: Making delegation and accountability work', European Journal of Political Research, $37: 3,309-333$.

Quiroz Flores, Alejandro (2009). 'The political survival of foreign ministers', Foreign Policy Analysis, 5:2, 117-133.

Real-Dato, José, and Miguel Jerez-Mir (2008). 'Cabinet dynamics in democratic Spain (1977-2008)', in Keith Dowding and Patrick Dumont (eds.), The Selection of Ministers in Europe: Hiring and firing. London: Routledge, 101-124.

Saalfeld, Thomas (2000). 'Germany: Stable parties, chancellor democracy and the art of informal settlement', in Wolfgang C. Müller and Kaare Strøm (eds.), Coalition Government in Western Europe. Oxford: Oxford University Press, 32-85.

Schleiter, Petra, and Edward Morgan-Jones (2010). 'Who's in charge? Presidents, assemblies, and the political control of semipresidential cabinets', Comparative Political Studies, 43:11, 1415-1441.

Shevchenko, Iulia (2005). 'Easy come, easy go: Ministerial turnover in Russia, 19902004', Europe-Asia Studies, 57:3, 399-428.

Sousa, Marcelo Rebelo de (1984). Os Partidos Políticos no Direito Constitucional Português. Braga: Livraria Cruz.

Strøm, Kaare (1985). 'Party goals and government performance in parliamentary democracies', American Political Science Review, 79:3, 738-754.

Strøm, Kaare (1990). 'A behavioral theory of competitive political parties', American Journal of Political Science, 34:2, 565-598. 
Strøm, Kaare, Wolfgang C. Müller, and Torbjörn Bergman (2003). Delegation and Accountability in Parliamentary Democracies. Oxford: Oxford University Press.

Tavares de Almeida, Pedro, and António Costa Pinto (2002). 'Portuguese ministers, 1851-1999: Social background and paths to power', South European Society \& Politics, 7:2, 5-40.

Tavits, Margit (2008). Presidents with Prime Ministers: Do Direct Elections Matter? Oxford: Oxford University Press.

Volkens, Andrea, Pola Lehmann, Theres Matthie, Nicolas Merz, Sven Regel, and Bernhard Weels (2017). Data from: The Manifesto Data Collection. Manifesto Project (MRG/CMP/MARPOR). Version 2017a [Dataset]. Wissenschaftszentrum Berlin für Sozialforschung (WZB). Retrieved from https://doi.org/10.25522/manifesto.mpdssa.2017a. 